\title{
Dioxin Residues in Beef Carcasses in Beni-Suef City, Egypt
}

\author{
F. A. Khalafalla ${ }^{1^{*}}$, Fatma H. M. Ali ${ }^{1}$, F. Schwägele ${ }^{2}$, Mariem A. Abdel-Wahab ${ }^{1}$ \\ ${ }^{1}$ Department of Food Hygiene, Faculty of Veterinary Medicine, Beni-Suef University, Beni-Suef, Egypt and ${ }^{2}$ Max \\ Rubner Institute, Federal Center of Nutrition and Food, Kulmbach, Germany
}

\begin{abstract}
A total of $\mathbf{1 0 0}$ fat samples were collected from slaughtered cattle at Beni-Suef slaughter house. Animals were randomly selected from the slaughter line. The age of the slaughtered cattle was normally less than three years (18-30 months). Samples were separately packed in plastic bags, identified and stored at $-18^{\circ} \mathrm{C}$ until analysis. The analysis was conducted at Max Rubbner Institute, Kulmbach, Germany for PCDDs, PCDFs and dl-PCBs. The average concentration sum for PCDD calculated as upper bound pg WHO-TEQ/g was $1.71 \mathrm{pg}$ WHO-TEQ/g fat. While the average concentration sum for PCDFs was $4.93 \mathrm{pg}$ WHO-TEQ/g fat. The average concentration sum of dl PCBs including non-ortho and mono-ortho PCBs was 5.091 pg WHO-TEQ/g fat. The total TEQ value for PCDD/Fs and dl-PCBs was $11.74 \mathrm{pg}$ WHO-TEQ/g fat. The residual levels of PCDD/Fs and dl-PCBs in the examined beef fat samples were higher than the proposed maximum permitted levels set by the European Commission (2006).
\end{abstract}

Meat and meat products constitute an important part of human diet as well as an important source of a wide range of nutrients, but may also carry some toxic substances. Since this should be limited to an unavoidable minimum, much attention is paid to the occurrence of these substances in food. Monitoring programs have been carried out in many countries with the purpose of avoiding the distribution of food stuffs that could pose a risk to human health if consumed (Lốpez-Alonso et al., 2000). Dioxins, which include polychlorinated dibenzo- $p$-dioxins (PCDDs), polychlorinated dibenzofurans (PCDFs), and dioxin-like polychlorinated biphenyls(dioxin-like PCBs) are among the most hazardous chemicals that exhibit potential risks for human and environment due to their persistence and lipophilic character (De Voogt et al., 1990; Fries, 1995 ), they tend to concentrate in the food chain. It has been concluded that ingestion of contaminated food of animal origin is the principal way of human exposure to these compounds, accounting for $>90 \%$ if compared to other ways such as inhalation and dermal contact. More

\footnotetext{
* Corresponding author. Tel.: +20 082/2327982; Fax: +20 082/2327982

E-mail address: fathykhalafalla@hotmail.com (Fathy Khalafalla)
}

specifically high portion of exposure to human is expected from great consumption of animal fat (Toyoda et al., 1999). The monitoring of raw meat for chemical residues is necessary to ascertain that approved compounds are not being misused and are not presenting a danger to consumers (Pullen, 1990). These contaminants mainly result from combustion processes of wastes, as chemical impurities in a range of manufactured organochlorine products, industrial processes, the manufacture of some pesticides, herbicides and fungicides, and pyrolysis processes (Olie and Buekens, 2007; Loutfy et al., 2007). Levels of dioxins and dioxin like PCBs have been determined in different countries by many authors ranging from $(0.03-13 \mathrm{pg}$ WHO-TEQ/g fat) for PCDDs, (0.03-2.9 pg WHO-TEQ/g fat) for PCDFs and (0.05-3 pg WHO-TEQ/g fat) for dl-PCBs (Loutfy et al., 2007; Kim et al., 2007; Kim et al., 2008). The aim of this study was to determine levels of polychlorinated dibenzo- $p$-dioxins (PCDDs), polychlorinated dibenzofurans (PCDFs) and dioxin like polychlorinated biphenyls (dlPCBs) in beef fat samples collected from slaughtered carcasses of native cattle in Beni-Suef city, Egypt.

\section{Materials and methods}

Sample collection. A total of 100 fat samples were collected from slaughtered cattle at BeniSuef slaughter house. Animals were randomly 
selected from the slaughter line. The age of the slaughtered cattle was normally less than three years (18-30 months). Samples were separately packed in plastic bags, identified and stored at $-18^{\circ} \mathrm{C}$ until analysis.

\section{Dioxins estimation}

Extraction. Extraction of $\mathrm{PCDD} / \mathrm{Fs}$ and $\mathrm{PCBs}$ was carried out using an Accelerated Solvent Extraction (ASE 200) device (Dionex, Sunny Vale, USA). The extraction cell was filled with dried sample material, drying substance and sea sand. For extraction n-hexane was used at a pressure 100 bar and a temperature of $100^{\circ} \mathrm{C}$. The samples were extracted in two cycles with a static time of $10 \mathrm{~min}$ each. The solvent of the extract was evaporated in a nitrogen stream in a water bath at $40^{\circ} \mathrm{C}$.

Gel permeation chromatography. For GPC, an LC glass column with an id of $25 \mathrm{~mm}$ was filled with $60 \mathrm{~g}$ bio-beads S-X3. The GPC (Abimed Gilson, Langenfeld, Germany) was carried out with a solvent mixture of cyclohexane: ethylacetate $(50: 50 \mathrm{v} / \mathrm{v})$ at a flow rate of $5 \mathrm{ml} / \mathrm{min}$ (wasting time 0-28 and collecting time 28-38 minutes).

Clean-up with florisil. The samples were evaporated under pressure, carefully brought to dryness with nitrogen and dissolved in $1 \mathrm{ml}$ toluene. Florisil (calcined for $12 \mathrm{~h}$ at $55^{\circ} \mathrm{C}$ ) was deactivated with $4 \%$ water. Three grams of deactivated florisil were filled into commercial disposable $8 \mathrm{ml}$ solid phase extraction (SPE) columns (id $12 \mathrm{~mm}$ ). After conditioning of the columns with $10 \mathrm{ml}$ toluene, the samples were applied and eluted with $60 \mathrm{ml}$ toluene to remove more polar compounds.

Clean-up with activated and endowed silica. After evaporation of the solvent to near dryness with rotation evaporation and nitrogen, the samples were dissolved in $1 \mathrm{ml}$-hexane. Commercially available $8 \mathrm{ml}$ SPE cartridges with an id of $12 \mathrm{~mm}$ were filled, in the following order with: $1-0.3 \mathrm{~g}$ drying substance, $2-1 \mathrm{~g} 33 \% \mathrm{NaOH}-$ Silica, 3- $0.25 \mathrm{~g}$ activated silica, 4- $2.5 \mathrm{~g} 44 \%$ $\mathrm{H}_{2} \mathrm{SO}_{4}$-Silica, 5- $0.5 \mathrm{~g} \quad 22 \% \mathrm{H}_{2} \mathrm{SO}_{4}$-Silica (all together about $5 \mathrm{~g}$ silica). After conditioning of the columns with $10 \mathrm{ml}$-hexane, the sample extracts were put on the columns and eluted with $60 \mathrm{ml} \mathrm{n}$ hexane.

Clean-up with activated charcoal. An LC glass column with an id of $12.5 \mathrm{~mm}$ was filled with 250 mg activated charcoal (Supelclean ENVI-Carb). For conditioning of the column, one blank run was made with a flow rate of $5 \mathrm{ml} / \mathrm{min}$ following program: 1) $20 \mathrm{ml}$ solvent mixture 1(nhexane/toluene; 99:1), 2) $20 \mathrm{ml}$ solvent mixture 2 (n-hexane/toluene; 75:75), 3) $60 \mathrm{ml}$ toluene (backflush mode), 4) cleaning and conditioning of the column with toluene and solvent mixture 1 in both flow directions to use the column filling again for a new sample.

Samples were concentrated to a volume of 1 $\mathrm{ml}$ and fractioned with the mentioned program: In the first fraction $(20 \mathrm{ml}$-hexane/toluene; 99:1) the di- and mono-ortho-substituted PCBs were collected, and in the second fraction $(20 \mathrm{ml} \mathrm{n}$ hexane/toluene; 75:25) the non-ortho-substituted PCBs were collected. In the third fraction $(60 \mathrm{ml}$ toluene) the PCDDs/Fs were collected in backflush mode because they have the characteristic to stick on activated charcoal. Cross-contamination was prevented by cleaning the activated charcoal column after each sample with solvent mixture 1 and with toluene in back-flush and in normal flow mode. Blank samples between normal samples could rule out possible cross-contamination.

GC-HRMS. Analysis of PCDD/Fs and dl-PCBs was performed with a gas chromatography (Hewlett-Packard 5860 series II gas chromatograph, Waldbronn, Germany) coupled with a VG Autospec Micromass (Manchester, UK) high-resolution mass spectrometer.

The quantification for PCDD/Fs and dl-PCBs was carried out by isotope dilution method USEPA 1613 (1994a) using relative response factors previously obtained from five standard solution injections. Two 13C-labeled PCDD and three 13C-labeled PCBs were added to the extracts before injection for the recovery calculations of $\mathrm{PCDD} / \mathrm{Fs}$ and dl-PCBs, respectively.

Calculation. PCDD/Fs and DL-PCBs TEQ are calculated using the toxic equivalent factors (TEFs) according to WHO (Van den Berg et al., 1998). The data below the detection limit (LOD) are calculated as lower, middle and upper bound values, assuming that all values of the different congeners are equal to zero, half the limit of detection or equal to their limit of detection, respectively. The numbering system of dl-PCBs congeners adapted by the International Union of Pure and Applied Chemistry (IUPAC) was used for confirmation and discussion of the results. 


\section{Results}

Table (1): PCDDs concentrations (pg/g fat based on fresh weight) in beef fat samples and relative contribution of individual PCDDs congeners.

\begin{tabular}{lccccc}
\hline Congeners & $\begin{array}{c}\text { No. of } \\
\text { samples }\end{array}$ & Maximum & Mean & $\begin{array}{c}\text { \% contribution to } \\
\text { sum PCDDs }\end{array}$ & $\begin{array}{c}\text { \% contribution to } \\
\text { sum PCDDs/Fs }\end{array}$ \\
\hline 2,3,7,8-TeCDD & 10 & 3.44 & 0.75 & 11.83 & 2.83 \\
$1,2,3,7,8-\mathrm{PeCDD}$ & 10 & 1.29 & 0.81 & 12.78 & 3.07 \\
$1,2,3,4,7,8-\mathrm{HxCDD}$ & 10 & 0.55 & 0.39 & 6.15 & 1.48 \\
$1,2,3,6,7,8-\mathrm{HxCDD}$ & 10 & 1.14 & 0.75 & 11.83 & 2.84 \\
$1,2,3,7,8,9-\mathrm{HxCDD}$ & 10 & 0.32 & 0.24 & 3.79 & 0.91 \\
$1,2,3,4,6,7,8-H p C D D$ & 10 & 2.18 & 1.57 & 24.76 & 5.94 \\
OCDD & 10 & 2.63 & 1.83 & 28.86 & 6.92 \\
Sum PCDDs & 10 & 10.52 & 6.34 & 100.00 & 23.99 \\
\hline
\end{tabular}

Table (2): PCDFs concentrations (pg/g fat based on fresh weight) in beef fat samples and relative contribution of individual PCDFs congeners.

\begin{tabular}{lccccc}
\hline Congeners & $\begin{array}{c}\text { No. of } \\
\text { samples }\end{array}$ & Maximum & Mean & $\begin{array}{c}\text { \% contribution } \\
\text { to sum PCDFs }\end{array}$ & $\begin{array}{c}\text { \% contribution to } \\
\text { sum PCDDs/Fs }\end{array}$ \\
\hline $2,3,7,8-\mathrm{TeCDF}$ & 10 & 7.55 & 1.06 & 5.28 & 4.01 \\
$1,2,3,7,8-\mathrm{PeCDF}$ & 10 & 1.35 & 0.43 & 2.14 & 1.63 \\
$2,3,4,7,8-\mathrm{PeCDF}$ & 10 & 9.51 & 7.72 & 38.45 & 29.22 \\
$1,2,3,4,7,8-\mathrm{HxCDF}$ & 10 & 5.59 & 4.33 & 21.56 & 16.39 \\
$1,2,3,6,7,8-\mathrm{HxCDF}$ & 10 & 4.46 & 3.59 & 17.88 & 13.59 \\
$2,3,4,6,7,8-\mathrm{HxCDF}$ & 10 & 1.99 & 1.34 & 6.67 & 5.07 \\
$1,2,3,7,8,9-\mathrm{HxCDF}$ & 10 & 0.16 & 0.10 & 0.50 & 0.38 \\
$1,2,3,4,6,7,8-\mathrm{HpCDF}$ & 10 & 1.19 & 0.93 & 4.63 & 3.53 \\
$1,2,3,4,7,8,9-\mathrm{HpCDF}$ & 10 & 0.51 & 0.35 & 1.74 & 1.32 \\
OCDF & 10 & 0.30 & 0.23 & 1.15 & 0.87 \\
Sum PCDFs & 10 & 29.22 & 20.08 & 100.00 & 76.01 \\
\hline
\end{tabular}

Table (3): DL-PCBs concentrations (pg/g fat based on fresh weight) in beef fat samples and relative contribution of individual non and mono- ortho PCBs congeners.

\begin{tabular}{lccc}
\hline \multicolumn{1}{c}{ Congeners } & Maximum & Mean & \% contribution to sum PCBs \\
\hline $3,3^{\prime}, 4,4^{\prime}-\mathrm{TCB}(77)^{*}$ & 50.20 & 21.60 & 0.46 \\
$3,4,4^{\prime}, 5-\mathrm{TCB}(81)$ & 5.60 & 3.61 & 0.08 \\
$3,3^{\prime}, 4,4^{\prime}, 5-\mathrm{PeCB}(126)$ & 55.00 & 42.76 & 0.91 \\
$3,3^{\prime}, 4,4^{\prime}, 5,5^{\prime}-\mathrm{HxCB}(169)$ & 17.60 & 13.55 & 0.29 \\
Sum non-ortho PCBs & 115.5 & 81.52 & 1.74 \\
2,3,3',4,4'-PeCB (105)* & 1277.80 & 551.45 & 11.79 \\
2,3,4,4',5-PeCB (114) & 165.80 & 105.81 & 2.26 \\
2,3',4,4'5-PeCB (118) & 4727.50 & 2645.48 & 56.56 \\
$2 ', 3,4,4^{\prime}, 5-\mathrm{PeCB}(123)$ & 326.50 & 139.18 & 2.98 \\
$2,3,3^{\prime}, 4,4^{\prime}, 5-\mathrm{HxCB}(156)$ & 672.20 & 440.60 & 9.42 \\
2,3,3',4,4',5'-HxCB (157) & 148.80 & 115.39 & 2.47 \\
2,3',4,4',5,5'-HxCB (167) & 1009.00 & 519.46 & 11.11 \\
2,3,3',4,4',5,5'-HpCB (189) & 115.90 & 78.30 & 1.67 \\
Sum mono-ortho PCBs & 8403.1 & 4595.67 & 98.26 \\
\hline
\end{tabular}

* IUPAC numbering system was used to classify PCBs congeners 
Table (4): Average upper bound (pg WHO-TEQ/g fat) values for PCDD congeners, sum PCDDs and sum PCDDs/Fs.

\begin{tabular}{lccc}
\hline \multicolumn{1}{c}{ Congeners } & $\begin{array}{c}\text { No. of } \\
\text { samples }\end{array}$ & TEQ & $\begin{array}{c}\text { \% contribution to TEQ } \\
\text { PCDDs/Fs }\end{array}$ \\
\hline 2,3,7,8-TeCDD & 10 & 0.746 & 11.21 \\
1,2,3,7,8-PeCDD & 10 & 0.813 & 12.23 \\
1,2,3,4,7,8-HxCDD & 10 & 0.039 & 0.58 \\
1,2,3,6,7,8-HxCDD & 10 & 0.0754 & 1.13 \\
1,2,3,7,8,9-HxCDD & 10 & 0.024 & 0.36 \\
1,2,3,4,6,7,8-HpCDD & 10 & 0.01574 & 0.23 \\
OCDD & 10 & 0.0001828 & 0.01 \\
Sum TEQ PCDDs & 10 & 1.7133 & 25.75 \\
Sum TEQ PCDDs/Fs & 10 & 6.652 & 100 \\
\hline
\end{tabular}

Table (5): Average upper bound (pg WHO-TEQ/g fat) values for PCDF congeners, sum PCDFs and sum PCDDs/Fs.

\begin{tabular}{lccc}
\hline \multicolumn{1}{c}{ Congeners } & $\begin{array}{c}\text { No. of } \\
\text { samples }\end{array}$ & TEQ & $\begin{array}{c}\text { \% contribution to TEQ } \\
\text { PCDDs/Fs }\end{array}$ \\
\hline 2,3,7,8-TeCDF & 10 & 0.1058 & 1.59 \\
$1,2,3,7,8-\mathrm{PeCDF}$ & 10 & 0.02125 & 0.32 \\
$2,3,4,7,8-\mathrm{PeCDF}$ & 10 & 3.8595 & 58.03 \\
$1,2,3,4,7,8-\mathrm{HxCDF}$ & 10 & 0.4329 & 6.52 \\
$1,2,3,6,7,8-\mathrm{HxCDF}$ & 10 & 0.3594 & 5.41 \\
$2,3,4,6,7,8-\mathrm{HxCDF}$ & 10 & 0.1346 & 2.02 \\
$1,2,3,7,8,9-\mathrm{HxCDF}$ & 10 & 0.0103 & 0.16 \\
$1,2,3,4,6,7,8-\mathrm{HpCDF}$ & 10 & 0.00928 & 0.14 \\
$1,2,3,4,7,8,9-\mathrm{HpCDF}$ & 10 & 0.0035 & 0.06 \\
OCDF & 10 & 0.000023 & 0.00 \\
Sum TEQ PCDFs & 10 & 4.936553 & 74.25 \\
Sum TEQ PCDDs/Fs & 10 & 6.652 & 100 \\
\hline
\end{tabular}

Table (6): Average upper bound (pg WHO-TEQ/g fat) values for non-ortho, mono-ortho PCBs congeners and sum dl-PCBs.

\begin{tabular}{|c|c|c|c|c|}
\hline \multicolumn{2}{|l|}{ Congeners } & \multirow{2}{*}{$\begin{array}{c}\text { No. of samples } \\
10\end{array}$} & \multirow{2}{*}{$\frac{\text { TEQ }}{0.00216}$} & \multirow{2}{*}{$\begin{array}{c}\text { \% contribution } \\
\text { to TEQ PCBs }\end{array}$} \\
\hline & 3,3',4,4'-TCB (PCB 77) & & & \\
\hline Non-ortho & 3,4,4',5-ТCB (PCB 81) & 10 & 0.00036 & 0.01 \\
\hline PCBs & 3,3',4,4',5-PeCB (РCB 126) & 10 & 4.276 & 84.00 \\
\hline & 3,3',4,4',5,5'-HxCB (РCB 169) & 10 & 0.1355 & 2.66 \\
\hline \multicolumn{2}{|c|}{ Sum TEQ non-ortho PCBs } & 10 & 4.41402 & 86.70 \\
\hline \multirow{8}{*}{$\begin{array}{l}\text { Mono-ortho } \\
\text { PCBs }\end{array}$} & 2,3,3',4,4'-PeCB (PCB 105) & 10 & 0.055145 & 1.08 \\
\hline & 2,3,4,4',5-PeCB (РCB 114) & 10 & 0.052905 & 1.04 \\
\hline & 2,3',4,4'5-PeCB (PCB 118) & 10 & 0.264548 & 5.20 \\
\hline & 2',3,4,4',5-PeCB (PCB 123) & 10 & 0.013918 & 0.27 \\
\hline & 2,3,3',4,4',5-НxCB (РCB 156) & 10 & 0.2203 & 4.33 \\
\hline & 2,3,3',4,4',5'-HxCB (РCB 157) & 10 & 0.057695 & 1.13 \\
\hline & 2,3',4,4',5,5'-HxCB (РCB 167) & 10 & 0.0051946 & 0.10 \\
\hline & $2,3,3^{\prime}, 4,4^{\prime}, 5,5^{\prime}-\mathrm{HpCB}$ (РCB 189) & 10 & 0.00783 & 0.15 \\
\hline \multicolumn{2}{|c|}{ Sum TEQ mono-ortho PCBs } & 10 & 0.6775356 & 13.30 \\
\hline \multicolumn{2}{|c|}{ Sum TEQ PCBs } & 10 & 5.09155 & 100 \\
\hline
\end{tabular}




\section{Discussion}

PCDD/Fs congener profiles. The results in Table (1) showed that the mean value of 7 PCDD congeners (sum PCDD) as upper bound values was $6.34 \mathrm{pg} / \mathrm{g}$ fat fresh weight with the maximum concentration of $10.52 \mathrm{pg} / \mathrm{g}$ fat fresh weight.

From the present data in Tables (1); 1, 2, 3, 4, 6, 7, 8-HpCDD and OCDD were the most abundant congeners in all samples with a mean value of 1.57 and $1.82 \mathrm{pg} / \mathrm{g}$ fat fresh weight, and contributed 24.76 and $28.86 \%$ respectively, to the total PCDDs concentration. The relative contribution of 1, 2, 3, 4, 7, 8-HxCDD and 1, 2, 3, $7,8,9-\mathrm{HxCDD}$ is very low and constitute 6.15 and $3.79 \%$ respectively, to the total PCDDs concentration with a mean value of 0.39 and 0.24 $\mathrm{pg} / \mathrm{g}$ fat fresh weight.

With regard to Table (2), it was found that the mean value of 10 PCDFs congeners (sum PCDFs) of $20.08 \mathrm{pg} / \mathrm{g}$ fat fresh weigh with the maximum concentration of $29.22 \mathrm{pg} / \mathrm{g}$ fat fresh weight.

A significant contribution of $2,3,4,7,8-$ PeCDF, 1, 2, 3, 4, 7, 8-HxCDF, 1, 2, 3, 6, 7, 8$\mathrm{HxCDF}$ and 2, 3, 4, 6, 7, 8-HxCDF has been observed in all samples represented $38.45 \%$, $21.56 \%, 17.90 \%$ and $6.67 \%$ to the total PCDFs concentrations with a mean value of $7.72,4.33$, 3.59 and $1.34 \mathrm{pg} / \mathrm{g}$ fat fresh weight, respectively. The 1, 2, 3, 7, 8, 9-HxCDF contribution was not remarkable in all examined samples $(0.50 \%)$ to the total PCDFs concentration with a mean value 0.10 $\mathrm{pg} / \mathrm{g}$ fat fresh weight (Tables 2).

From the recorded data in Table (1 and 2) it is obvious that the pattern of PCDD/Fs in all analyzed samples is characterized generally by the dominance of PCDFs (76.01\%), while PCDDs constitute $(23.99 \%)$ in relation to the total PCDD/Fs concentrations.

Nearly similar results were recorded by $\mathrm{Yu}$ et al., (2006); Loutfy et al., (2007); Kim et al., (2008).

Various toxic effects on immune, nervous, endocrine and reproductive systems, and potential carcinogenic effects have been reported for PCDD/Fs as reported by WHO, (1999).

PCDFs usually dominate the typical fingerprints combustion sources. This agrees with that reported by Huang and Buekens (1995); Loutfy et al., (2007). The dominance of 2, 3, 4, 7, 8-PeCDF, 1, 2, 3, 4, 7, 8-HxCDF and 1, 2, 3, 6, 7, $8-\mathrm{HxCDF}$ has been reported in the chimney soot samples arising from wood burning reported by Bacher et al., (1992), and the UK ambient air samples from an area where the domestic burning of wood and coal is widespread (Lohmann et al., 2000). Moreover, Kim et al., (2005) reported that PCDFs are generally produced from incineration processes. On the other hand, Ferrario et al., (1996) found that beef fat samples from USA showed higher PCDDs contribution than PCDFs and suggested that pentachlorophenol-treated wood was one of the sources of PCDD contamination in USA and this was in agreement with Fries et al., (2002) and Huwe et al., (2004) as well as with Focant et al., (2002) who found the same congener profiles in Belgium beef samples.

In general, it was found that the profiles obtained in this study are close to the profiles obtained from the combustion of household wastes (Wevers et al., 2004). These results clearly reflect the situation in Egypt, where domestic and some agricultural solid waste open burning is quite common practice, and about one-fifth of the municipal solid waste is burned in open dump sites allover the country. Also no sludge of industrial waste is incinerated in Egypt. Incineration is very limited to some hospitals and some veterinary educational unit. However, some of the newly introduced industries such as pulp and paper bleaching and some metallurgic works constitute other sources of emission which agrees with Loutfy et al., (2007).

DL-PCBs congener profiles. The average concentration values of 4 non-ortho and 8 monoortho PCBs are given in (Tables 3) along with maximum value for each congeners in $\mathrm{pg} / \mathrm{g}$ lipid weight basis. This table illustrated that all nonortho and mono-ortho PCBs congeners were observed in all investigated samples with a mean value of 81.52 and $4595.67 \mathrm{pg} / \mathrm{g}$ lipid weight basis for non-ortho and mono-ortho PCBs respectively. From Tables (3) it was obvious that the most abundant non-ortho PCBs congener was PCB 126 constituting $52.45 \%$ of the total amount of nonortho PCBs with a mean value of $42.76 \mathrm{pg} / \mathrm{g}$ fat fresh weight, while PCB 81 constitutes $4.43 \%$ and represents the lowest non-ortho $\mathrm{PCB}$ concentration with a mean value of $3.61 \mathrm{pg} / \mathrm{g}$ fat fresh weight.

With regard to mono-ortho PCBs it was obvious that PCB 118 was the most abundant mono-ortho PCBs congener, comprising up to $57.57 \%$ of the total amount of mono-ortho PCBs 
with a mean value of $2645.48 \mathrm{pg} / \mathrm{g}$ fat fresh weight. While PCBs 189 was the lowest monoortho PCBs concentration constituting $1.70 \%$ with a mean value of $78.30 \mathrm{pg} / \mathrm{g}$ fat fresh weight (Table $3)$.

In general, it was found that the pattern of dlPCBs in all analyzed samples is characterized generally by the dominance of mono-ortho PCBs (98.26\%) to the total dl-PCBs concentrations.

Exposure to polychlorinated biphenyls (PCBs) compounds resulted in various harmful effects including reproductive toxicity, immune suppression, birth defects, cancer and developmental and behavioural changes as mentioned by Safe, (1994).

Commercial PCB mixtures have been used in a wide variety of applications, including dielectric fluids in capacitors and transformers, heat transfer fluids, hydraulic fluids, lubricating and cutting oils and as additives in pesticides, paints, copying paper, carbonless copy paper, adhesives, sealants and plastics (Erickson, 1997).

On the contrary, Agency for Toxic Substances and Disease Registry, (2000) reported that although the manufacture, processing and distribution of polychlorinated biphenyls (PCBs) have been prohibited in almost all industrial countries since the late 1980 s, their entry into the environment throughout the world still occurs. Improper waste disposal, both of house hold and industrial waste and leaks from electrical equipment and hydraulic systems still in use, are the major source of PCB emissions into the environment.

TEQs calculation and health implications. To assess the toxicity associated with presence of $\mathrm{PCDD} / \mathrm{Fs}$ and dioxin like PCBs (non-ortho and mono-ortho PCBs) in foodstuffs, the WHO has proposed toxic equivalency factors (WHO-TEFs) for each of the toxic congeners, which relate the toxicity of the different congeners to that of 2, 3, 7, 8-TCDD, the most toxic one (Van den Berg et al., 1998). Combining the concentration found for each congener with its corresponding WHO-TEF, a single WHO-TEQ value is obtained, suitable to compare levels between different studies and with the maximum content in food allowed by different international bodies.

PCDD/Fs TEQs. The average concentration values for individual $\mathrm{PCDD} / \mathrm{F}$ congeners as well as the average concentration sums for $\mathrm{PCDD} / \mathrm{Fs}$ calculated as upper bound pg WHO-TEQ/g values are given in Tables (4 and 5).

From the present data it is clear that PCDF contribution to $\mathrm{PCDD} / \mathrm{Fs}$ TEQ was predominated in all examined samples (74.25\%), while PCDD constitute about $25.75 \%$ of PCDD/Fs TEQ.

Nearly similar results were reported by Focant et al., (2002); Kim et al., (2008). On the contrary Ferrario et al., (1996) reported that the total contribution of PCDD were higher than PCDFs in the USA beef fat.

Concerning the contribution of individual congeners to $\mathrm{PCDD} / \mathrm{Fs}$ TEQ values, it is appear that $58.03 \%$ of PCDD/Fs TEQ is actually due to $2,3,4,7,8$-PeCDFs congener. With regard to PCDD, 1, 2, 3, 7, 8-PeCDD and 2, 3, 7, 8-TeCDD which have the highest toxic equivalent factors (TEFs) were the predominant congeners accounting for 12.23 and $11.21 \%$ of the PCDD/Fs TEQ.

Generally, it can be concluded that the residual TEQ in the examined fat samples was mostly from PCDFs.

DL-PCBs TEQ. The average concentration values for 4 non-ortho PCBs congeners, 8 mono-ortho PCBs congeners and the average concentration sum for dl-PCBs expressed in picogram WHO$\mathrm{TEQ} / \mathrm{g}$ fat in upper bound limit of determination were given in Table (6).

It is obvious that non-ortho PCBs congeners constitute the largest portion of the total PCBs TEQ with a relative contribution of $86.7 \%$ of the total PCBs TEQ. This agrees with Bordajandi et al., (2004) who stated that in most cases the largest contribution to the TEQ value is due to dlPCBs corresponded to non-ortho PCBs.

Concerning the contribution of individual congeners to the PCBs TEQ value, PCB 126 seemed to be the most important one represented $84 \%$ of the total PCBs TEQ. This was in close agreement with Loutfy et al., (2007) who reported that congener PCB 126 is the most toxic one, having the highest TEF and accounting for the larger contribution of $\mathrm{PCBs}$ to the TEQ. It contributes more or less $80 \%$ of the total PCBs.

Regarding to mono-ortho PCBs congeners, it is worth noticing that although the congeners exhibiting the highest concentration in all samples were PCB 118, 167, 156, and 105, when data are expressed in WHO-TEQ, they represent a very low relative contribution to the total PCBs TEQ 
value due to their low TEF value. In this respect, Loutfy et al., (2007) found that mono-ortho PCBs congeners were detected in all samples with congener 118 as the most abundant, followed by congener 105.

Total TEQ. From the present data can be concluded that all examined fat samples are heavily contaminated (6.65 pg TEQ PCDD/Fs /g fat and $5.09 \mathrm{pg}$ TEQ PCBs/g fat) in comparison with the European Union National Average Concentrations (3 pg TEQ/g fat) (European Commission, 2001), and the future EU limit (European Commission, 2006), if PCB, are included.

\section{References}

Agency for Toxic Substances and Disease Registry (ATSDR) (2000): Toxicological profile for polychlorinated biphenyls (update). Public Health Service, Atlanta (GA): ATSDR, US.

Bacher, R.; Swerev, M. and Ballschmiter, K. (1992): Profile and pattern of monochlorodibenzodioxins through octachlorodibenzodioxins and octachlorodibenzofurans in chimney deposits from wood burning. Environ. Sci. Technol., 26: 1649-1655.

Bordajandi, L.R.; Gómez, G.; Abad, E.; Rivera, J.; del Mar Fernández-Bastón, M.; Blasco, J. and González, M. J. (2004): Survey of persistent organochlorine contaminants (PCBs, PCDD/Fs, and PAHs), heavy metals $(\mathrm{Cu}, \mathrm{Cd}, \mathrm{Zn}, \mathrm{Pb}$, and $\mathrm{Hg}$ ), and arsenic in food samples from Huelva (Spain): levels and health implications. J. Agric. Food Chem., 52: 9921001.

De Voogt, P.; Wells, D. E.; Reutergardh, L. and Brinkman, U.A.T. (1990): Biological activity, determination, occurrence of planar, mono- and di-ortho PCBs.Int. J. Environ. Anal. Chem., 40: 1-46.

Erickson, M.D. (1997): Analytical Chemistry of PCBs. $2^{\text {nd }}$ ed. CRC Press, Boca Raton, Florida, USA.

European Commission (2001): Council Regulation (EC) No 2375/2001 of 29 November 2001 a mending Commission Regulation (EC) No 466/2001 setting maximum levels for certain contaminants in foodstuffs. Official J. Eur. Commun., L321: 1-5.

European Commission (2006): Setting maximum levels for certain contaminants in foodstuffs. SANCO/2005/03995/00/00/TRA rev 3. Draft.

Ferrario, J.; Byrne, C.; Mc Daniel, D. and Dupuy Jr., A. (1996): Determination of 2,3,7,8-chlorine-substituted dibenzo- $p$-dioxins and furans at the part per trillion level in United States beef fat using high-resolution gas chromatography/high resolution mass spectrometry. Anal. Chem., 68:647-652.

Focant, J. F.; Eppe, G. ; Pirard, C. ; Massart, A.C. ; André, J. E. and De Pauw, E. (2002): Levels and congener distributions of PCDDs, PCDFs and non-ortho PCBs in Belgian foodstuffs. Assessment of dietary intake. Chemosphere, 48:167-179.

Fries, G. F.; Feil, V. J.; Zaylski, R.G.; Bialek, K. M. and Rice, C.P. (2002): Treated wood in livestock facilities: relationships among residues of pentachlorophenol, dioxins and furans in wood and beef. Environ. Pollut., 116: 301-307.

Fries, G. F. (1995): A review of the significance of animal food products as potential pathways of human exposure to dioxins. J. Anim. Sci., 73: 1639-1650.

Huang, H. and Buekens, A. (1995): On the mechanisms of dioxin formation in combustion processes. Chemosphere, 31 : 4099-4117.

Huwe, J.; Hoffman, M.; Deyrup, C.; Hulebak, K.; Larsen, G.; Zaylskie, R.; Lorentzsen, M. and Clinch, N. (2004): A survey of PCDD/Fs and coplanar PCBs in the US meat and poultry supply in 2002-2003. Organohalogen Compd, 66: 1942-1946.

Kim, M.; Kim, D. G.; Yun, J. S. and Son, S. W. (2008): Relationship of PCDD/Fs congener profiles between beef and raw milk in South Korea. Chemosphere, 70: 1563-1567.

Kim, M.; Kim, S.; Yun, J. S.; Kim, D.G. and Chung, G. S. (2007): Background levels and dietary intake of PCDD/Fs in domestic and imported meat in South Korea. Chemosphere, 69: 479-484.

Kim, B. H.; Lee, S. J.; Mun, S. J. and Chang, Y. S. (2005): A case study of dioxin monitoring in and around an industrial waste incinerator in Korea. Chemosphere, 58: 1589-1599.

Lohmann, R.; Northcott, G. L. and Jones, K.C. (2000): The contribution of diffuse domestic burning as a source of $\mathrm{PCDD} / \mathrm{Fs}$, PCBs and PAHs to the UK atmosphere. Environ. Sci. Technol., 34: 2892-2899.

López-Alonso, M.; Benedito, J. L.; Miranda, M.; Castillo, C.; Hernández, J. and Shore, R. F. (2000): Toxic and trace elements in liver, kidney and meat from cattle slaughtered in Galicia (NW Spain). Food Addit. Contam., 17 (6): 447-457.

Loutfy, N.; Fuerhacker, M.; Tundo, P.; Raccamelli, S. and Ahmed, M. T. (2007): Monitoring of polychlorinated dibenzo- $p$-dioxins and dibenzofurans, dioxin-like PCBs, and polycyclic aromatic hydrocarbons in food and feed samples from Ismailia City, Egypt. Chemosphere, 66:1962-1970.

Olie, K. and Buekens, A. (2007): A comparison of PCDD/F profiles in combustion residues. Organohalogen Compd, 69: 2443-2446.

Pullen, M. M. (1990): Residues.pp.135-154. In Meat and Health (Advances in Meat Research), Vol.6 (Pearson, A.M. and Dutson, T.R., Eds.). Elsevier Science Publisher LTD, Amsterdam, Holland.

Safe, S. H. (1994): Polychlorinated biphenyls (PCBs): environmental impact, biochemical and toxic responses, and implications for risk assessment. Crit. Rev. Toxicol., 24: 87149.

Toyoda, M.; Uchibe, H.; Yanagi, T.; Kono, Y.; Hori, T. and Iida, T. (1999): Dietary daily intake of PCDDs, PCDFs and coplanar PCBs by total diet study in Japan. J. Food Hyg. Soc. Jpn., 40: 98-110.

Van den Berg, M.; Birnbaum, L.' Albertus, T. C.; Brunström, B.; Cook, Ph.; Feeley, M.; Giesy, J.P.; Hanberg, A.; Hasegawa, R.; Kennedy, S.W.; Kbiak, T.; Christian, J.; Rolaf Van Leeuwen, F. X.; Djien Lion, A.K.; Nolt, C.; Peterson, R. E.; Poellinger, L.; Safe, S.; Schrenk, D.; Tillitt, D.; Tysklind, M.; Younes, M.; Waern, F. and Zacharewski, T. (1998): Review. Toxic equivalency factors (TEFs) for PCBs, PCDDs, PCDFs for humans and wildlife. Environ. Health Persp., 106: 12. 
Wevers, M.; De Fré, R. and Desmedt, M. (2004): Effect of backyard burning on dioxin deposition and air concentrations. Chemosphere, 54: 1351-1356.

WHO (1999): PCDD/Fs and their effects on human health. Fact Sheet No. 225.
Yu, B.W.; Jin, G.Z.; Moon, Y. H.; Kim, M. K.; Kyoung, J. D. and Chang, Y.S. (2006): Emission of PCDD/Fs and dioxin-like PCBs from metallurgy industries in S. Korea. Chemosphere, 62: 494-501.

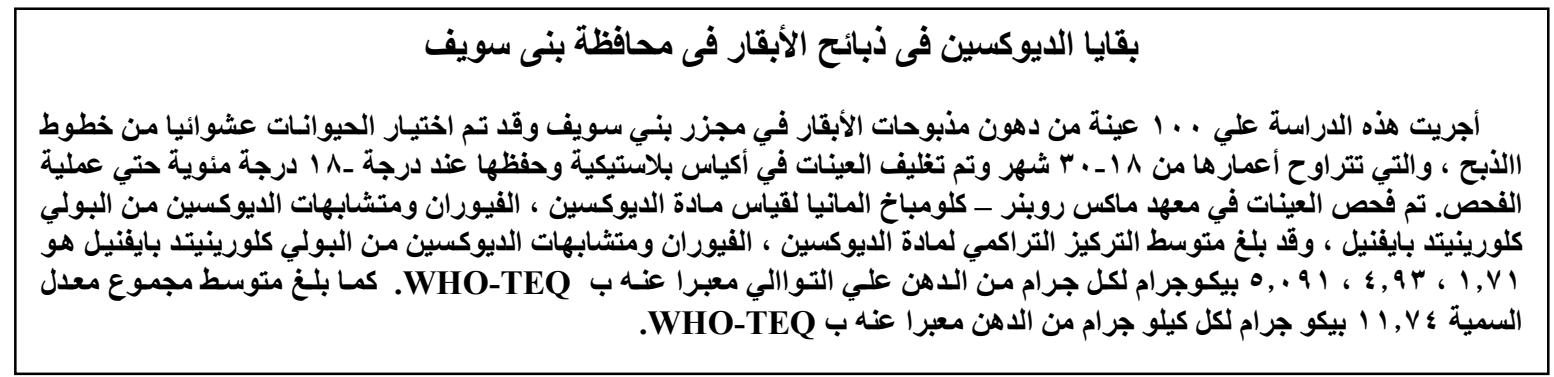

